\title{
Dynamics of Polymyxa graminis and Indian peanut clump virus (IPCV) infection on various monocotyledonous crops and groundnut during the rainy season
}

\author{
P. Delfosse ${ }^{a *}$, A. S. Reddy ${ }^{a}$, K. Thirumala Devi ${ }^{\mathrm{a}}$, A. Legrève ${ }^{\mathrm{b}}$, J. Risopoulos ${ }^{\mathrm{b}}$, D. Doucet ${ }^{\mathrm{b}}$, \\ P. Shoba Devi ${ }^{a}$, H. Maraite ${ }^{b}$ and D. V. R. Reddy ${ }^{a}$

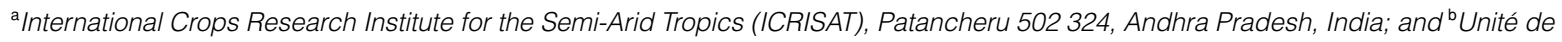 \\ Phytopathologie, Université catholique de Louvain, Place Croix du Sud 2 Bte 3, B-1348 Louvain-la-Neuve, Belgium
}

\begin{abstract}
The progress of Indian peanut clump virus (Hyderabad isolate; IPCV-H) and its vector Polymyxa graminis in various monocotyledonous crops and groundnut was studied during the 1994, 1995 and 1996 rainy seasons in a naturally infested field in India. The roles of rainfall and temperature in the dynamics of infection by both the virus and its vector were analysed by exposing young seedlings for short periods in the field. Of the host crops studied, wheat, followed by barley, showed the highest virus incidence, although $P$. graminis was rarely observed in roots of wheat and was not detected in those of barley. The roots of maize, pearl millet and sorghum plants infected by $P$. graminis showed intense colonization by sporosori. IPCV accumulated in systemically infected maize plants; the sorghum and pearl millet cultivars studied showed a transient presence of IPCV-H. Rice was seldom infected by the virus and P. graminis was not detected in its roots. Groundnut was a systemic host for the virus, although during these experiments no P. graminis was found in its roots. Groundnut appeared to be susceptible to infection, mostly in the early stages of crop development, and the rate of IPCV-H transmission in groundnut seeds was highest $(13 \%)$ for plants infected when young. The seedtransmission rate quickly decreased in plants showing symptoms 1 month after sowing. Time of infection had little influence on groundnut pod yield, which was always reduced by $>60 \%$ in infected plants. There was some evidence that the quantity and distribution of rainfall influenced the incidences of IPCV-H and P. graminis: high rainfall resulted in high incidences of the virus and P. graminis, and a weekly rainfall of $14 \mathrm{~mm}$ was sufficient for $P$. graminis to initiate infection. Temperatures prevailing during the rainy season ranged from 23 to $30^{\circ} \mathrm{C}$ and were found to be conducive to natural virus transmission. These results suggest measures to be explored for controlling peanut clump disease.
\end{abstract}

Keywords: cereals, epidemiology, groundnut, IPVC, Polymyxa graminis, rainfall, temperature

\section{Introduction}

Peanut clump disease causes significant losses in groundnut (peanut, Arachis hypogaea) crops in West Africa and the Indian subcontinent (Reddy et al., 1999). Indian peanut clump virus (IPCV), a member of the genus Pecluvirus (Torrance \& Mayo, 1997; Reddy et al., 1999), is the causal agent of the disease in India and Pakistan (Reddy et al., 1983; Reddy et al., 1988; Delfosse et al., 1995). All currently known pecluviruses are seed- and soil-transmitted (Reddy et al., 1988; Konaté \& Barro, 1993). IPCV is

*To whom correspondence should be addressed.

†Present address: ICRISAT Sahelian Center, BP 12404 Niamey, Niger (via Paris). E-mail: p.delfosse@cgiar.org

Accepted 23 May 2002 transmitted in seeds of groundnut, millets, wheat and maize and therefore is of particular importance in germplasm exchange (Reddy et al., 1998; Delfosse et al., 1999; Reddy et al., 1999). IPCV was shown to be transmitted by the obligate parasite Polymyxa graminis, which is soilborne (Ratna et al., 1991). The soilborne habit of the vector and its survival as highly resistant resting spores are responsible for the patchy appearance of the disease and its recurrence year after year in almost the same areas of a field. IPCV induces severe stunting in groundnut, indicating that infection usually occurs at an early stage of crop growth (Reddy et al., 1988; Thouvenel et al., 1988). However, various degrees of stunting were noticed during surveys conducted in Asia and West Africa, and it was thought that stunting severity depended on the age of the plants when they were infected (Dollet et al., 1993; Manohar et al., 1995). In India, Reddy et al. (1988) 
reported an influence of the date of sowing on disease incidence. Groundnut crops grown during the post-rainy season and crops sown in the rainy season well beyond the onset of monsoon rains mostly escaped the disease. The authors concluded that temperature was an important factor influencing natural virus transmission.

IPCV and its vector, P. graminis, have wide host ranges, which include many monocotyledonous as well as dicotyledonous weeds and crops. Although $P$. graminis transmits the virus to dicotyledonous crops, it does not extensively colonize their roots. Sporosori (resting spore clusters or cystosori) were rarely detected in such plants and were few in number (Ratna et al., 1991; Delfosse et al., 1996; Legrève, 1999; Legrève et al., 2000). Also, roots of naturally virus-infected groundnut plants failed to induce the disease when incorporated into sterile sand, whereas infected sorghum and pearl millet roots were sources of inoculum (Thouvenel et al., 1988; Ratna et al., 1991; Delfosse et al., 1996). For these reasons, dicotyledonous plants are considered as 'fortuitous' hosts that are unlikely to contribute to build-up of clump disease inoculum. In contrast, monocotyledonous hosts such as maize, pearl millet and sorghum are regarded as 'preferred' hosts for $P$. graminis because of its relatively high incidence and multiplication in them, as measured by the number of sporosori present in their roots (Ratna et al., 1991; Delfosse et al., 1996; Legrève, 1999). These particular cereals are also hosts of IPCV and some of them transmitted the virus through seed; preferred hosts are therefore suspected to play an important role in the perpetuation and spread of virus inocula (Reddy et al., 1999).

Resistance to IPCV could not be identified in any of nearly 9000 Arachis germplasm lines tested. Attempts to control the disease by the application of soil biocides and soil solarization, although effective, were found to be either hazardous or uneconomical (Dhery et al., 1975; Reddy et al., 1988; Reddy et al., 1999). The work reported here was undertaken mainly to study the epidemiology of peanut clump disease in the hope of formulating cultural methods of disease control. Parameters studied included the role of monocotyledonous crops, which are often rotated or intercropped with groundnut, in the establishment, survival and spread of peanut clump disease, and the environmental factors crucial for transmission by $P$. graminis.

\section{Materials and methods}

The experiments were conducted during the consecutive 1994, 1995 and 1996 rainy seasons in a field $(0 \cdot 35$ ha) naturally infested with the Hyderabad isolate of IPCV (IPCV-H) (Nolt et al., 1988) on the ICRISAT farm $\left(18^{\circ} \mathrm{N}\right.$, $\left.78^{\circ} \mathrm{E}\right)$, Andhra Pradesh, India. The soil was sandy, with $84 \%$ sand, $10 \%$ loam and $6 \%$ clay, and showed a $\mathrm{pH}$ close to neutral. In the first experiment, the progress of P. graminis and IPCV-H incidence was studied in plants grown under field conditions and sequentially uprooted during the rainy season to assess the influence of climatic factors on infection. A second experiment was conceived to refine the study of climatic factors influencing the incidence of peanut clump disease. The trial consisted of exposing young plants for short periods in the field, during which time rainfall (including irrigation) and temperature were recorded. After field exposure, plants were transplanted to a greenhouse in conditions conducive to IPCV-H and P. graminis multiplication to facilitate virus and vector detection, irrespective of when the plants were infected. In this way, the climatic factors that prevailed during the period of exposure in the field were expected to influence the incidence of infection by $P$. graminis and IPCV-H. The experimental details are summarized in Table 1. For each season, four new replicate blocks were demarcated in areas where IPCV-H incidence ranged from 60 to $80 \%$ in groundnut crops grown during the rainy season preceding each experimental period. Because the areas with uniform infestation were small, the number of plants analysed was limited (Table 1). In 1994, four virusfree plots, adjacent to the infested one, were also demarcated in the same field, in an area where IPCV-H had not been recorded in groundnut crops during the past 7 years. These plots were included to assess if $P$. graminis occurred with similar incidence in infested and virus-free soils.

\section{Progress of IPCV-H incidence in groundnut crops}

For each season, the part of the field not used for experiments was sown with groundnut to achieve a population of approximately $100 \times 10^{3}$ plants ha ${ }^{-1}$. Seeds were treated with thiram at $3 \mathrm{~g} \mathrm{~kg}^{-1}$ to prevent damping-off. Groundnut was grown to monitor the progress of clump disease incidence over time by scoring the crop for typical symptoms (Reddy et al., 1988). Infected plants were marked according to the date they showed symptoms. In 1996, the entire groundnut production from four major virus-infested areas was harvested 4.5 months after sowing, and the pods were sorted according to the date symptoms appeared. The yield and seed transmission rate assessed by an ELISA test on cotyledons (Reddy et al., 1998) were calculated for each group and compared to those of healthy plants.

\section{Progress of $P$. graminis and IPCV-H incidence in sequentially uprooted, field-grown plants}

For each season, the crops listed in Table 1 were sown in the field. Plants were carefully uprooted at regular intervals in each plot. Roots were washed free of soil under tap water, stained, and analysed by light microscopy for the presence of $P$. graminis sporosori as described by Maraite et al. (1988). For assessment of $P$. graminis incidence, only plants with sporosori in their roots were included. In naturally infected plants, sporosori were the predominant stage observed, and identification of $P$. graminis on the basis of the plasmodial and zoosporangial stages was found to be unreliable as other soil organisms produced similar structures in roots. As the season progressed, the root system grew substantially and therefore root fragments sampled at random over the whole root system, representing $\approx 10 \%$ of the total root length, were stained 
Table 1 Experimental details of field trials in 1994, 1995 and 1996 rainy seasons

\begin{tabular}{|c|c|c|c|}
\hline Factor & 1994 & 1995 & 1996 \\
\hline Preceding cropping system (November-March) & fallow & wheat & wheat \\
\hline \multicolumn{4}{|l|}{ Cultivations } \\
\hline Sowing & 1 July & 24 June & 25 June \\
\hline First sampling/transplanting from/to field & 11 July & 6 July & 12 July \\
\hline Last sampling for plants grown in field & 5 Sep & 11 Sep & 20 Sep \\
\hline Last sampling for plants exposed in field & 5 Sep & 9 Oct & 8 Oct \\
\hline Experiment repeated in virus-free area & yes & no & no \\
\hline \multicolumn{4}{|l|}{ Scoring dates for clump symptoms in groundnut } \\
\hline July & 14,29 & 31 & $12,19,26$ \\
\hline August & 12,30 & 23 & 9,23 \\
\hline September & - & 28 & 27 \\
\hline Harvesting of groundnut & First or second week of November & & \\
\hline \multicolumn{4}{|l|}{ Crops and cultivars studied } \\
\hline Sorghum (Sorghum bicolor) ICSV-88036 & yes & yes & yes \\
\hline Pearl millet (Pennisetum glaucum) ICMH-451 & yes & yes & yes \\
\hline Finger millet (Eleusine coracana) HR-374 & yes & yes & no \\
\hline Maize (Zea mays) DHM-103 & no & yes & yes \\
\hline Wheat (Triticum aestivum) RR-21 & no & yes & yes \\
\hline Barley (Hordeum vulgare) RD-103 & no & yes & no \\
\hline Rice (Oryza sativa) Rasi & no & yes & yes \\
\hline Groundnut (Arachis hypogaea) NCAc 17090 & no & yes & yes \\
\hline \multicolumn{4}{|l|}{ Design $^{\mathrm{a}}$} \\
\hline Number of plants analysed per observation ${ }^{b}$ & 4 & 4 or 8 & 6 \\
\hline Number of observations over time & 9 & 7 & 10 \\
\hline Subplot size $(1 \text { replicate } \times 1 \text { species })^{c}$ & 2-m row & 4-m row & $1 \times 1 \mathrm{~m}$ \\
\hline Whole plot size $(m)^{c}$ & $2 \times 2$ & $4 \times 2$ & $6 \times 1$ \\
\hline Distance between plants $(\mathrm{cm})$ & 5 & 5 & 5 \\
\hline Distance between rows $(\mathrm{cm})$ & 25 & 25 & 25 \\
\hline \multicolumn{4}{|l|}{ Virus detection } \\
\hline in leaves & yes & yes & yes \\
\hline in roots & no & yes & yes \\
\hline
\end{tabular}

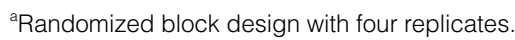

bThis number applies to field-grown plants. For plants exposed for short periods this number is the optimum targeted, but it often varied according to the survival rate of plants.

cPlot size and shape were adjusted to fit the area available in IPCV-H-infested patches.

and analysed. A portion of the youngest leaf and root samples were collected and tested by ELISA to assess the presence of the virus. In 1994, only leaves were assayed.

\section{Plants exposed in the field to determine the conditions conducive to infection}

Seeds of the crops listed in Table 1 were disinfected by soaking for $10 \mathrm{~min}$ in $5 \%$ sodium hypochlorite (commercial solution), rinsed thoroughly with distilled water, and germinated. Two-day-old seedlings were transplanted to polyvinyl chloride pipes ( $32 \mathrm{~mm}$ diameter, $100 \mathrm{~mm}$ long) closed at one end with a piece of sterile cotton cloth held with a rubber band. The pipes were held in a tray to facilitate watering and transport, and filled with sterile sand (1-2 $\mathrm{mm}$ particle size). The seedlings were watered daily with half-strength Hoagland's solution, pH 6.5 (Adams et al., 1986) until 1 week old, when they were transplanted into $40 \mathrm{~mm}$ holes in the field. The cloth holding the seedling was removed, and the seedling was placed in the hole with minimal disturbance to the root system and aerial parts. Seedlings were exposed in the field for 1 week and then carefully uprooted, except in 1995 when plants collected from 31 July onwards were exposed for 2 weeks. When a set of exposed plants was uprooted, a new set of seedlings was transplanted to the field on the same day.

Leaf samples were collected from the exposed plants and tested by ELISA. The roots were not tested at the time of retrieval from the field because sampling could have resulted in the loss of recent $P$. graminis or IPCV-H infection. Instead, to amplify infection and facilitate detection of both the virus and its vector, the plants were transplanted to sterile sand in $50 \mathrm{~mL}$ glass culture tubes (1994 and 1995 seasons) (Maraite et al., 1988) or, in the 1996 season, to an automatic immersion system with individual watering for each plant (unpublished data). Transplanted plants were maintained in a greenhouse for a few weeks (8-10 weeks in 1994; 6 weeks in 1995; 4-5 weeks in 1996 ) at $25-30^{\circ} \mathrm{C}$, a temperature range known to favour multiplication of IPCV and P. graminis (Reddy et al., 1988; Legrève et al., 1998). After the incubation period, roots were analysed for the presence of $P$. graminis and 
surviving plants were tested by ELISA to detect the presence of the virus in both leaves and roots.

\section{ELISA}

IPCV-H was detected by the penicillinase-based form of double antibody-sandwich ELISA (Sudarshana \& Reddy, 1989; Reddy et al., 1998). For the field-grown and field-exposed plants, virus incidence was recorded as the number of plants that tested positive in ELISA. For the groundnut crop sown in the remaining part of the field, virus incidence was based on visual symptoms corroborated by random tests on leaf extracts by ELISA.

\section{Weather data}

Daily mean soil temperature was recorded at $10 \mathrm{~cm}$ below the soil surface. Daily rainfall and irrigation were recorded in the field with tipping-bucket rain gauges (Texas Electronics Inc., Dallas, TX, USA, model TR5251), or rainfall data were obtained from the Meteorological Observatory of ICRISAT-Patancheru. Dataloggers (Campbell Scientific, Inc., Logan, UT, USA, model CR 10) were used to record weather data in the field.

\section{Data analysis}

For the plants grown in the field and uprooted at regular intervals during the rainy season, the number of plants analysed was consistent for all the observations, allowing data analysis using ANOVA on angular transformed percentages [arc-sine transformation: $\theta=\operatorname{arc} \operatorname{sine}(\sqrt{x})$ ] developed for binomial proportions (Snedecor \& Cochran, 1967; Gomez \& Gomez, 1984). For plants exposed for short periods in the field, the number of plants that survived varied greatly in 1995 , therefore the data were not analysed statistically. In 1994 and 1996, mortality was low and the data were analysed by ANOvA. The influence of time of infection by IPCV-H on yield and seed transmission frequencies in groundnut was analysed by linear regression.

\section{Results}

\section{Progress of IPCV-H incidence in groundnut crops}

In each year, virus symptoms first appeared about 2 weeks after sowing, the incidence increasing during July and August and reaching a plateau by September (Fig. 1). Final incidence was much less in 1994 (563 plants) and 1995 (775 plants) than in 1996 (4242 plants), when the incidence observed in this particular field was the greatest since ICRISAT initiated studies on clump disease in 1983. Moreover, in 1996 infected groundnut plants were recorded in new areas of the field, contributing to the majority of the incidence. Because there is at least a 2week delay between infection and symptom detection (Reddy et al., 1988), infections observed must nearly all have occurred between sowing and the end of July, during the early stages of crop growth. Virus incidence was negligible in the groundnut field in areas used during each preceding experimental season, as if sequential sampling of plants had exhausted the soil inoculum.

For the three rainy seasons, the mean soil temperature remained in the range $23-30^{\circ} \mathrm{C}$, known to be conducive to $P$. graminis development (Figs 2-4) (Legrève et al., 1998). The 1994 season was the driest, with the highest daily rainfall reaching only $40.4 \mathrm{~mm}$ during the last week of August (Fig. 2d). The 1995 season was wetter than 1994 , with a regular distribution of rainfall. There was at least one significant daily rainfall $(>40 \mathrm{~mm}$ ) recorded each month (Fig. 3j). In 1996, the rainfall was not as evenly distributed as in 1994 and 1995, and it was necessary to irrigate the crops in July and at the end of the season in September and October (Fig. 4f). The 1996 summer (April until the end of June) was predominantly dry $(87 \mathrm{~mm})$ compared to $1994(144 \mathrm{~mm})$ and 1995 $(136 \mathrm{~mm})$. A high rainfall $(35 \mathrm{~mm})$ occurred on 25 June, coinciding with the sowing of groundnut, and favourable soil-moisture conditions were assured by irrigation throughout the 1996 rainy season. Exceptionally high rainfall was recorded in August; one daily rainfall reached $107 \mathrm{~mm}$.
Figure 1 Progress of IPCV-H incidence in groundnut crops based on visual symptoms during the 1994, 1995 and 1996 rainy seasons. The groundnut population was $\approx 35 \times 10^{3}$ plants each season.

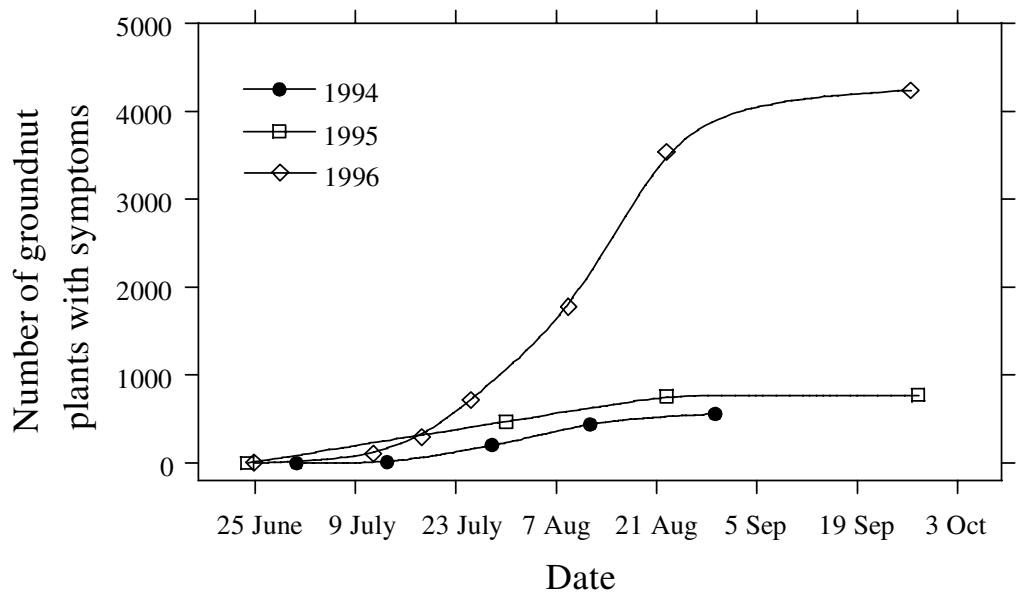



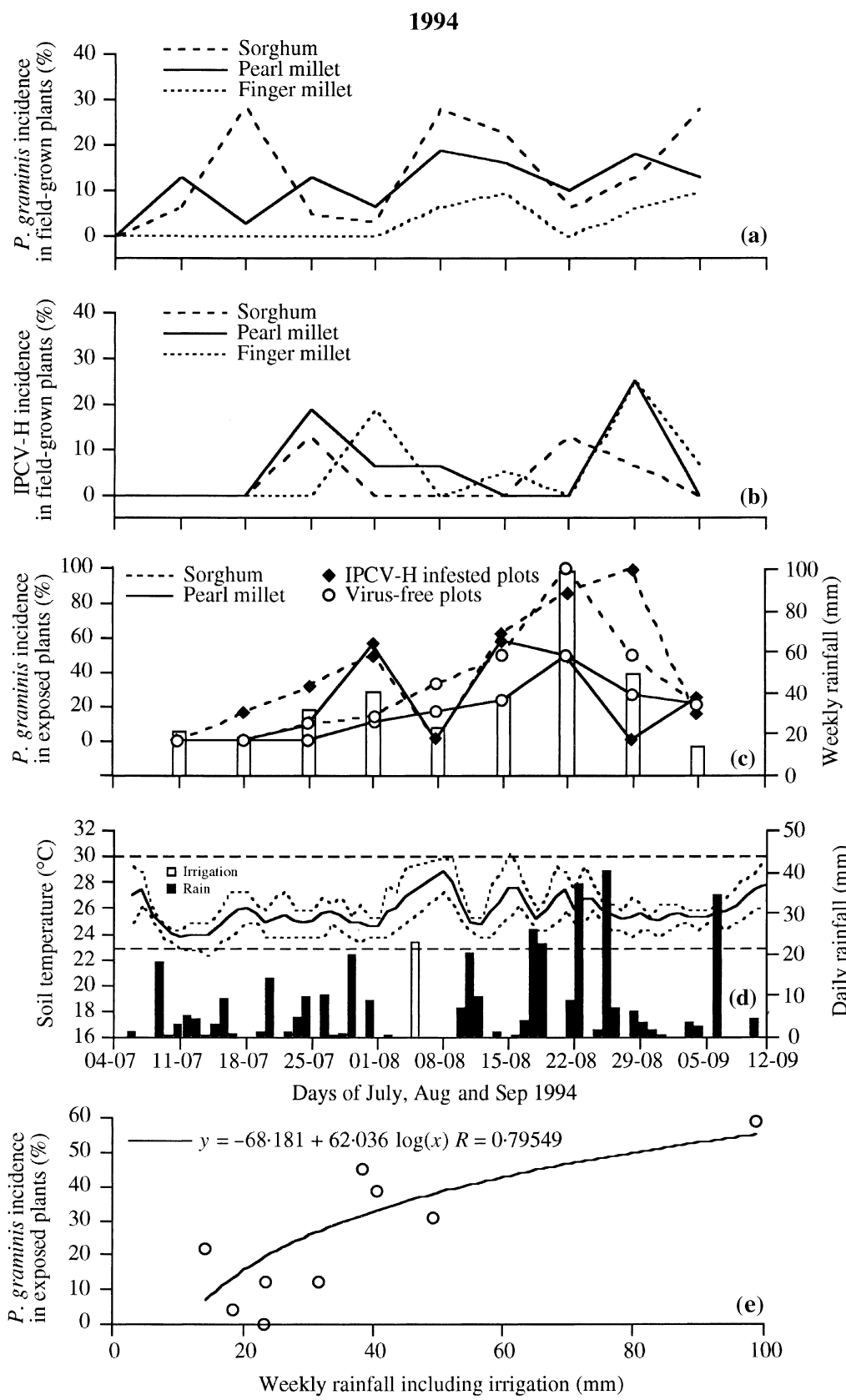

Figure 21994 rainy season. (a) Progress of Polymyxa graminis incidence in roots of three cereals sown on 4 July, grown in the field and uprooted at weekly intervals (mean percentage of total number of plants grown in IPCV-H-

infested and virus-free plots). (b) Progress of IPCV-H incidence in leaves of plants grown in virus-infested plots. (c) Progress of $P$. graminis incidence in roots of plants exposed for 1 week in the field in IPCV-H-infested and virus-free areas, then maintained in a greenhouse for 8 10 weeks before analysis, and corresponding weekly rainfall recorded during the period of exposure in the field. (d) Daily mean, minimum and maximum soil temperatures at $10 \mathrm{~cm}$ below the soil surface, and daily rainfall (black bars) and irrigation (white bars). Horizontal lines border the temperature range known to be conducive to $P$. graminis development. (e) Relationship between mean $P$. graminis incidence calculated for all plants exposed in IPCV-H-infested and virus-free areas and corresponding weekly rainfall (including irrigation) recorded during the period of exposure in the field.

Infected plants from the 1996 rainy season were analysed for their yield and the rate of virus transmission through seed (Table 2). Irrespective of the age when plants showed symptoms, the yield loss in infected plants relative to healthy plants was always $>60 \%$. There was only a slight tendency for plants infected later in the season to produce higher yields, as indicated by the positive slopes of the linear regressions between pod yield (pod yield $=1.748+0.034 \times \mathrm{DAS} ; P=0 \cdot 018)$ and seed weight (seed weight $=1 \cdot 084+0 \cdot 013 \times$ DAS; $\quad P=0 \cdot 001$ ) vs number of days after sowing (DAS) for symptom detection. However, the frequency of virus transmission through seed (ST) was lower in plants that were infected later in the season than in early-infected plants $(\log [\mathrm{ST}]=1 \cdot 893-0.489 \times \log [\mathrm{DAS}] ; P<0 \cdot 001)$. The seed transmission rate quickly decreased in plants showing symptoms 1 month after sowing.

Progress of IPCV-H and $P$. graminis incidence in groundnut and monocotyledonous plants sequentially sampled or exposed for short periods in the field

1994

Sequentially uprooted plants. Incidences of $P$. graminis and IPCV-H in finger millet, pearl millet and sorghum are given in Table 3. Over the entire season, finger millet and 

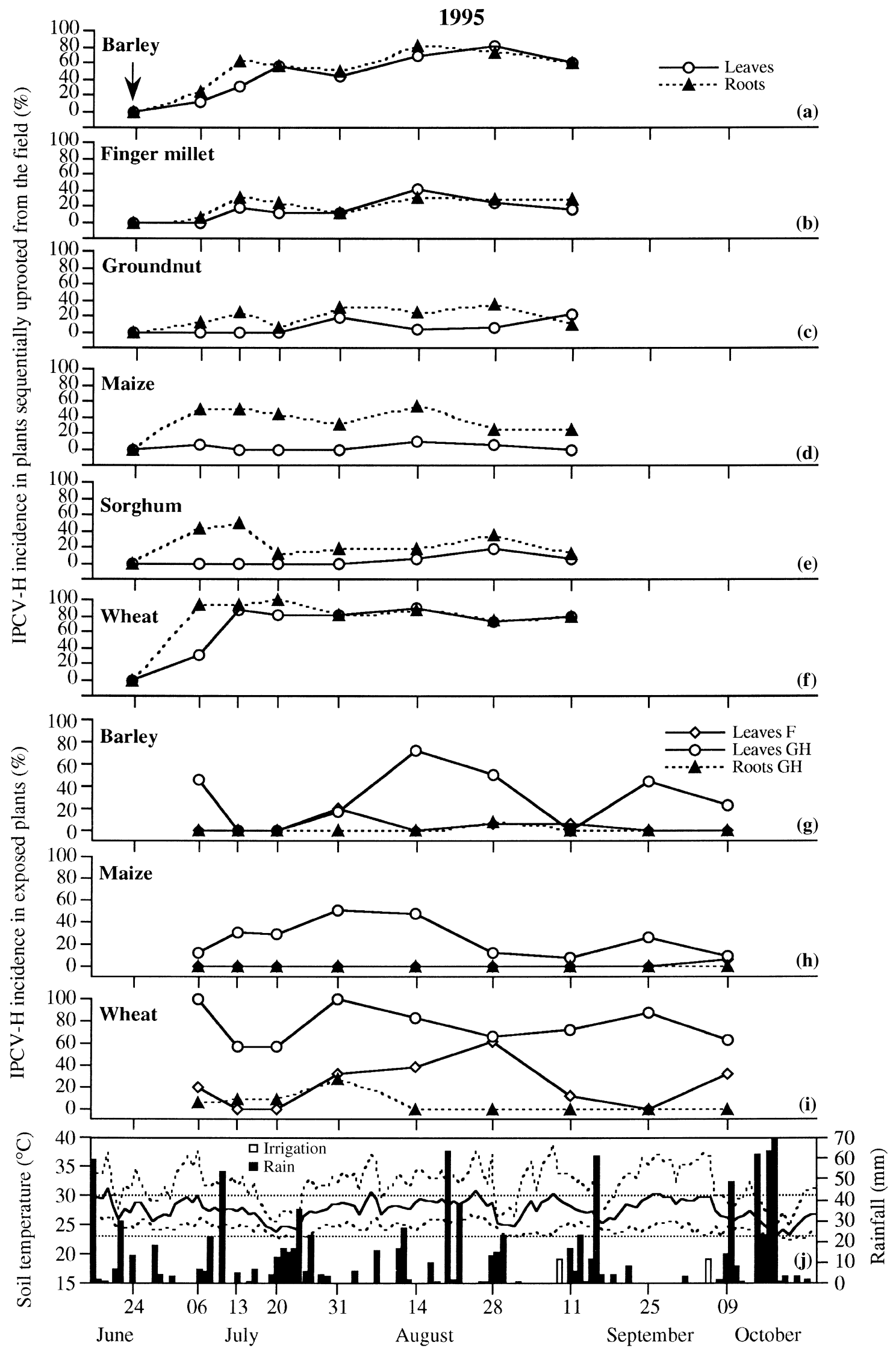
Table 2 Yield components and seed transmission rates in IPCV-infected groundnut plants on successive dates during the 1996 rainy season

\begin{tabular}{|c|c|c|c|c|c|c|}
\hline \multirow{2}{*}{$\begin{array}{l}\text { Scoring } \\
\text { date }\end{array}$} & \multirow{2}{*}{$\begin{array}{l}\text { Cumulative no. } \\
\text { symptomatic plants }\end{array}$} & \multirow{2}{*}{$\begin{array}{l}\text { Pod yield } \\
\left(\mathrm{kg} \mathrm{ha}^{-1}\right)\end{array}$} & \multirow{2}{*}{$\begin{array}{l}\text { No. seeds } \\
\text { per plant }\end{array}$} & \multirow{2}{*}{$\begin{array}{l}\text { Seed yield } \\
\text { per plant }{ }^{a}(g)\end{array}$} & \multicolumn{2}{|c|}{ Seed transmission ${ }^{b}$} \\
\hline & & & & & $n_{i} / N$ & (\%) \\
\hline 12 July & 110 & $235 \pm 27$ & $6 \cdot 9 \pm 1 \cdot 3$ & $1 \cdot 0 \pm 0 \cdot 2$ & $56 / 413$ & $(13.5 \pm 1 \cdot 9)$ \\
\hline 19 July & 298 & $213 \pm 13$ & $4 \cdot 7 \pm 1 \cdot 7$ & $1 \cdot 0 \pm 0 \cdot 1$ & 107/808 & $(13 \cdot 2 \pm 2 \cdot 4)$ \\
\hline 26 July & 716 & $221 \pm 134$ & $6 \cdot 8 \pm 3 \cdot 0$ & $1 \cdot 4 \pm 0 \cdot 2$ & $222 / 3228$ & $(6.9 \pm 1.9)$ \\
\hline 9 Aug & 1776 & $326 \pm 44$ & $8 \cdot 2 \pm 1 \cdot 4$ & $1 \cdot 6 \pm 0 \cdot 3$ & $138 / 5680$ & $(2 \cdot 4 \pm 1 \cdot 2)$ \\
\hline 23 Aug & 3540 & $321 \pm 18$ & $9 \cdot 2 \pm 0 \cdot 4$ & $1 \cdot 7 \pm 0 \cdot 1$ & 9/475 & $(1 \cdot 9 \pm 1 \cdot 0)$ \\
\hline 27 Sep & 4242 & $394 \pm 83$ & $10 \cdot 1 \pm 1 \cdot 6$ & $1 \cdot 9 \pm 0 \cdot 3$ & $7 / 405$ & $(1.7 \pm 0.9)$ \\
\hline Healthy ${ }^{c}$ & - & $1258 \pm 547$ & $23 \cdot 6 \pm 10 \cdot 8$ & $6 \cdot 4 \pm 3 \cdot 0$ & - & - \\
\hline
\end{tabular}

${ }^{a}$ Means and standard deviations of four replications.

${ }^{\mathrm{b}}$ Number of seeds infected/number of seeds tested $\left(n_{\mathrm{i}} / N\right)$ and as a percentage.

${ }^{\mathrm{c}}$ Four sets of 50 plants analysed. Pod yield and number of seeds per plant were statistically higher for healthy plants than for infected ones (Tukey's significant difference test, $P \leq 0 \cdot 05$ ).

\begin{tabular}{|c|c|c|c|}
\hline \multirow[b]{2}{*}{ Crop } & \multirow[b]{2}{*}{ IPCV-H ${ }^{b}$} & \multicolumn{2}{|l|}{ P. graminis $^{\mathrm{C}}$} \\
\hline & & IPCV-H-infested area & Virus-free area \\
\hline \multicolumn{4}{|c|}{ Sequentially uprooted plants } \\
\hline Finger millet & $8 / 144(7 \cdot 8)$ & $7 / 144(5 \cdot 5)$ & $5 / 144(3 \cdot 8)$ \\
\hline Pearl millet & $9 / 144(7 \cdot 8)$ & $31 / 144(21 \cdot 0)$ & $3 / 144(2 \cdot 5)$ \\
\hline Sorghum & $5 / 144(5 \cdot 0)$ & $27 / 144(17 \cdot 7)$ & $18 / 144(12 \cdot 5)$ \\
\hline $\mathrm{SED}_{\text {crop }}$ (2 d.f.) & $(2 \cdot 6)^{\mathrm{NS}}$ & $(6 \cdot 1)^{\star}$ & $(2 \cdot 9)^{\star \star}$ \\
\hline \multicolumn{4}{|l|}{ Exposed plants } \\
\hline Pearl millet & $0 / 111$ & $29 / 111(22 \cdot 4)$ & $18 / 104(18 \cdot 0)$ \\
\hline Sorghum & $0 / 80$ & $27 / 80(35 \cdot 1)$ & $13 / 51(28 \cdot 4)$ \\
\hline $\operatorname{SED}_{\text {crop }}$ (1 d.f.) & & $(5 \cdot 5)^{\star}$ & $(6 \cdot 1)^{\mathrm{NS}}$ \\
\hline
\end{tabular}

Table 3 Polymyxa graminis and IPCV-H incidence ${ }^{a}$ in cereals either grown during the 1994 rainy season, uprooted at weekly intervals and directly analysed, or exposed for 1 week in the field then transplanted to sterile sand and maintained in a greenhouse to favour $P$. graminis development

${ }^{a}$ Combined data from nine samplings collected from 11 July to 5 September Figures represent number of infected plants out of number of plants analysed; the angular transformed percentage is given in brackets.

bIPCV-H incidence was assessed by ELISA only in the virus infested-area.

${ }^{\mathrm{c}}$ Polymyxa graminis incidence was assessed in both areas.

NS, Not significant; ${ }^{* *}$, significant at $1 \%$ level; ${ }^{*}$, significant at $5 \%$ level.

pearl millet sampled in the virus-free plots showed lower incidences of $P$. graminis than sorghum. In the virusinfested area, finger millet showed a lower P. graminis incidence than the two other cereals, but the three crops responded in a consistent manner over time (the interaction of crop $\times$ sampling date was not significant, $P=$ 0.93). The three cereals showed similarly low IPCV-H incidences $(<7 \%)$. When conditions were favourable for infection of sorghum, they were also favourable for infection of the other two crops.

The progress of incidence during the rainy season was irregular for both virus and fungus (Fig. 2a,b). Virus and vector incidences were not cumulative over time. In the three cereals, the progress of virus incidence in leaves approximately followed that of $P$. graminis in roots with a delay of $\approx 1-2$ weeks. Finger millet showed a virus incidence of $20 \%$ on 1 August, while none of these plants showed the presence of $P$. graminis. The three crops appeared to be transient hosts for the virus, possibly a result of the sampling of young leaf tissues in which IPCV$\mathrm{H}$ was not yet detectable. Indeed, IPCV-H incidence was low during the first 3 weeks of August, when the mean soil temperature was high and the maximum mean air temperature was close to $30^{\circ} \mathrm{C}$, a temperature very favourable to the growth of these tropical cereals. Additionally, in midSeptember the plants remaining in the infested patches and tested by ELISA for the presence of the virus in leaf extracts showed a very low virus incidence. The virus was detected in only 13 of 100 finger millet, none of 380 pearl millet and one of 330 sorghum plants.

Figure 31995 rainy season. (a-f) Progress of IPCV-H incidence in roots and leaves of crop plants grown in the field and sequentially uprooted. Arrow indicates date of sowing. (g-i) Progress of IPCV-H incidence in plants exposed for 1 week (sampled on 6, 13 and 20 July) or 2 weeks (sampled from 31 July to 9 October) in the infested field, then maintained in a greenhouse for 6 weeks before analysis. ELISA tests were performed on leaves immediately after the period of exposure in the field (F) and, after the incubation period under greenhouse conditions (GH), on leaves and roots. (j) Daily mean, minimum and maximum soil temperatures at $10 \mathrm{~cm}$ below soil surface (horizontal lines border the temperature range known to be conducive to Polymyxa graminis development), daily rainfall (black bars) and irrigation (white bars). 

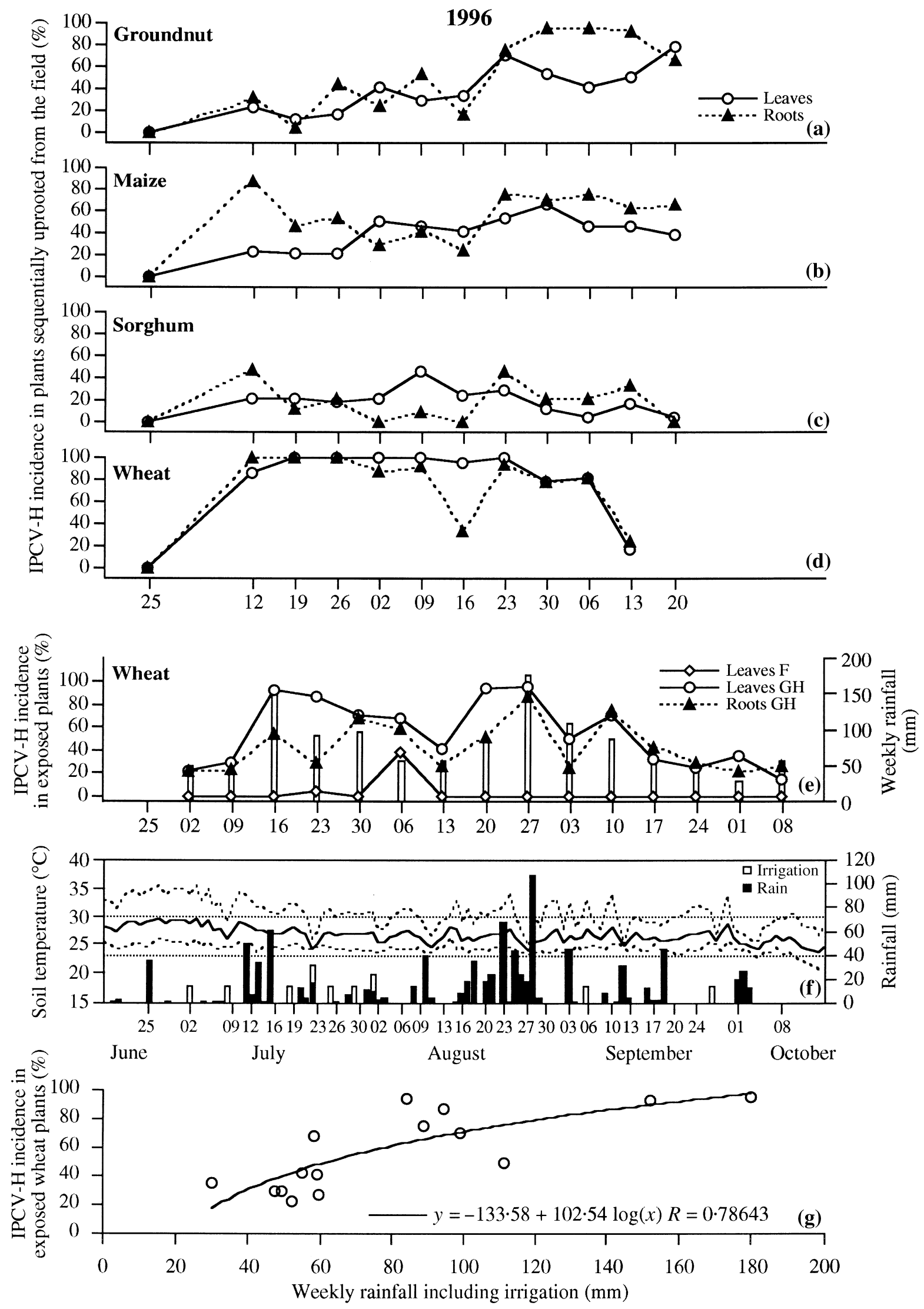
Field-exposed plants. In 1994, IPCV-H was never detected in the leaves of field-exposed plants when assayed at the time of retrieval from the field. The two species tested, sorghum and pearl millet, were hosts for P. graminis sporosori (Table 3 ). The plasmodiophorid was detected for the first time in the samples collected on 18 July (Fig. 2c), when only sorghum was infected. A peak of infection was observed on 1 August, when sorghum and pearl millet showed equal percentages of infection and it was mainly the plants collected in the IPCV$\mathrm{H}$-infested plots that were infected (Table 3 ). Based on observations made over the entire season, it was apparent that $P$. graminis incidence on plants exposed for 1 week in the field was positively correlated with weekly rainfall (WR) recorded during the period of exposure (Fig. 2c,e). A logarithmic regression could be established between the combined incidence of $P$. graminis in the roots of sorghum and pearl millet plants, and the weekly rainfall recorded during the week of exposure (P. graminis incidence $=-68 \cdot 181+62 \cdot 036 \log [\mathrm{WR}], \quad R=0 \cdot 80$ with 7 d.f.). The lowest weekly rainfall recorded during the season $(14 \mathrm{~mm})$ was sufficient to induce $P$. graminis infection.

\section{5}

Sequentially uprooted plants. Virus incidence in pearl millet (five of 160 plants, only roots tested positive) and rice (four of 160 plants) was negligible over the entire season and the results are not presented. The progress of virus incidence in the other hosts is presented in Fig. 3(a-f). The virus was detected in the first root samples collected on 6 July, 12 days after sowing. All species except pearl millet were hosts for IPCV-H, based on detection of virus antigen in root extracts. The virus was also detected in leaves of all species except pearl millet. Wheat showed the highest incidence in roots $(94 \%)$, followed by maize $(50 \%)$. Virus incidence in wheat reached almost its maximum at the second sampling, 2 weeks after sowing, when the incidence in wheat leaves $(88 \%)$ was similar to that observed in roots $(94 \%)$. There was thus $\approx 1$ week's delay for virus migration from roots to leaves during the early stages of wheat growth. Wheat remained infected in both leaves and roots throughout the experiment. Surprisingly, in September the virus was detected in the leaves of groundnut plants that did not show the presence of the virus in their roots. Otherwise, in most cases, irrespective of species, virus incidence was higher in roots than in leaves $(P \leq 0 \cdot 001)$. The virus occurred with a very low incidence in leaves of sorghum (10 of 160 plants) and rice (one of 160 plants). In the case of groundnut, virus was detected in leaves $\approx 3$ weeks later than in roots, coinciding with the appearance of symptoms in the crop.

The crop plants were also analysed for the presence of P. graminis. From a total of 160 plants analysed per species, one maize, 10 pearl millet, one finger millet and 10 sorghum plants were found to be infected by the plasmodiophorid. Infected plants had a high number of sporosori in their roots. Although the other crops were infected by the virus, $P$. graminis could not be detected in their roots.

During the last week of October 1995, the plants remaining in the experimental infested plots were tested by ELISA for the presence of the virus in leaf extracts: 27 of 150 finger millet, none of 190 pearl millet, none of 100 rice and three of 155 sorghum plants tested positive.

Field-exposed plants. In 1995, all the crops except rice were found to be hosts for IPCV. Finger millet (nine of 128 plants), groundnut (three of 142 plants), sorghum (one of 141 plants), and pearl millet (one of 137 plants) showed very low virus incidences over the season. Wheat, barley and maize showed high virus incidences in leaves, with wheat showing the highest incidence of all crops (Fig. 3g-i). Wheat was also the crop, along with barley, for which a significant number of leaf samples tested positive directly after the period of plant exposure in the field. IPCV migration from roots to shoots was thus very fast in wheat and barley. Generally speaking, after incubation in the greenhouse, virus incidence in leaves was higher than in roots. This was probably caused by root rotting in glass culture tubes during the incubation period, as a result of which viral infection was lost.

Polymyxa graminis was detected in seven of 141 sorghum, seven of 137 pearl millet and one of 141 maize plants. The mortality of plants exposed in the field and then maintained in the greenhouse was relatively high during the 1995 season. The survival rate varied from $46 \%$ for wheat to $77 \%$ for maize, and therefore no obvious correlation was observed between virus incidence in the crops and rainfall recorded during the period of exposure in the field.

\section{6}

Sequentially uprooted plants. Among the six crops tested in 1996, wheat again showed the highest virus incidence over the entire season (Fig. $4 \mathrm{a}-\mathrm{d}$ ) for both leaves and roots. A large number of wheat plants were moribund or dead at the end of the growing season. The virus was readily detected in all the crops from the first sampling on 12 July, 17 days after sowing. Pearl millet (16 of 261 plants) and rice (10 of 252 plants) showed low virus incidences over the entire season. For groundnut (129 of

Figure 41996 rainy season. (a-d) Progress of IPCV-H incidence in roots and leaves of crop plants grown in the field and sequentially uprooted. Arrow indicates date of sowing. (e) Progress of IPCV-H incidence in wheat plants exposed for 1 week in the infested field, then maintained in a greenhouse for 4-5 weeks before analysis, and corresponding weekly rainfalls (including irrigation) recorded during the period of exposure in the field. ELISA tests were performed on leaves immediately after the period of exposure in the field (F) and, after the incubation period under greenhouse conditions $(\mathrm{GH})$, on leaves and roots. (f) Daily mean, minimum and maximum soil temperatures at $10 \mathrm{~cm}$ below soil surface (horizontal lines border the temperature range known to be conducive to Polymyxa graminis development), daily rainfall (black bars) and irrigation (white bars). (g) Relationship between IPCV-H incidence in wheat and weekly rainfall (including irrigation) that occurred during the period of exposure in the field. 
Table 4 IPCV-H incidence ${ }^{\mathrm{a}}$ in various crop plants exposed for 1 week in the field during the 1996 rainy season, then transplanted into autoclaved sand and maintained in a glasshouse to favour virus replication

\begin{tabular}{|c|c|c|c|}
\hline \multirow[b]{3}{*}{ Crop } & \multicolumn{3}{|c|}{ IPCV-H incidence } \\
\hline & \multirow{2}{*}{$\begin{array}{l}\text { After exposure } \\
\text { in field, leaves }\end{array}$} & \multicolumn{2}{|c|}{ After incubation in greenhouse $\left(25-30^{\circ} \mathrm{C}\right)$} \\
\hline & & Leaves & Roots $^{b}$ \\
\hline Groundnut & $1 / 369(2 \cdot 7)$ & 3/369 (3.4) & $15 / 369(9 \cdot 1)$ \\
\hline Maize & $0 / 373(2 \cdot 3)$ & $16 / 366(7 \cdot 2)$ & $21 / 372(8 \cdot 9)$ \\
\hline Pearl millet & $2 / 348(3 \cdot 1)$ & $7 / 342(5 \cdot 0)$ & $8 / 348(4 \cdot 6)$ \\
\hline Rice & $0 / 320(2 \cdot 5)$ & 10/292 (6.2) & $4 / 303(4 \cdot 0)$ \\
\hline Sorghum & $0 / 358(2 \cdot 4)$ & 3/332 (3.6) & $3 / 350(3 \cdot 4)$ \\
\hline Wheat1 & $10 / 362(4 \cdot 6)$ & $163 / 312(49 \cdot 5)$ & $43 / 346(39 \cdot 4)$ \\
\hline $\mathrm{SED}_{\text {crop }}(5$ d.f. $)$ & $(0 \cdot 76)^{\star}$ & $(1 \cdot 87)^{\star \star \star}$ & $(1 \cdot 85)^{\star \star *}$ \\
\hline $\mathrm{SED}_{\text {crop x organ }}(10$ d.f. $)$ & & $(1.58)^{\star \star \star}$ & \\
\hline Total & $13 / 2130(2 \cdot 9)$ & $202 / 2013(12 \cdot 5)$ & $194 / 2088(11 \cdot 6)$ \\
\hline $\mathrm{SED}_{\text {organ }}(2$ d.f. $)$ & & $(0 \cdot 64)^{\star \star \star}$ & \\
\hline
\end{tabular}

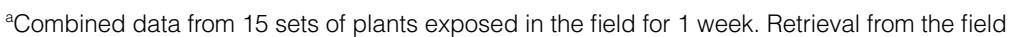
started on 2 July and ended on 8 October. Figures represent number of plants infected out of number of plants analysed for each category; the angular transformed percentage is given in brackets. The target number of plants exposed in the field for each crop was 360 . The number of plants actually analysed indicates the survival rate of plants after exposure in the field or incubation in the greenhouse.

${ }^{\mathrm{b}}$ Also included plants found moribund during incubation and tested for the presence of virus in roots

${ }^{*}$, significant at $5 \%$ level; ${ }^{* *}$, significant at $0 \cdot 1 \%$ level.
243 plants), maize (137 of 241 plants) and wheat (176 of 297 plants), virus incidence was above $50 \%$ and tended to follow a cumulative curve, with some variations (Fig. 4a-d). For instance, all the crops showed a reduced virus incidence in their roots for the sampling on 16 August, which was preceded by a period of two relatively dry weeks (Fig. 4f).

Young groundnut plants showed similar virus incidences in both roots and leaves. Later in the season, an increasing delay was observed between detection of the virus in leaves and roots (Fig. 4a). From the total of plants analysed during the 1996 season, groundnut $(P \leq 0 \cdot 001)$, maize $(P \leq 0 \cdot 001)$ and wheat $(P=0 \cdot 045)$ showed higher virus incidences in roots than in leaves (Tukey's HSD test).

During the first week of October 1996, leaves on plants remaining in the plots were all tested by ELISA. The results showed that 34 of 50 groundnut, 45 of 141 maize, three of 202 pearl millet, one of 128 rice and 43 of 197 sorghum plants were infected; all wheat plants were dead.

Over the entire 1996 season, $P$. graminis was readily detected in the roots of 16 of 227 maize, 38 of 225 pearl millet and 140 of 249 sorghum plants. In sorghum, P. graminis incidence was zero 1 week after sowing, but increased to a plateau ( $>50 \%$ ) 3 weeks after sowing; it was significantly higher $(P \leq 0 \cdot 001)$ than the virus incidence in sorghum leaves (53 of 249 plants) and roots (55 of 249 plants). Polymyxa graminis incidence in pearl millet varied between 0 and $38 \%$. Infected wheat plants (two of 191) had few sporosori in their roots.

Field-exposed plants. All the crops were found to be hosts for IPCV in 1996 (Table 4), while P. graminis was detected exclusively in maize roots ( 11 of 372 plants). The survival rate of the plants after field exposure ranged from almost $90 \%$ for rice to $100 \%$ for groundnut. After the incubation period in the greenhouse, the survival rate was higher than in 1994 and 1995, ranging from 91\% for rice to $86 \%$ for wheat. Wheat again showed the highest IPCV incidence and a higher incidence in leaves than in roots $(P \leq 0.001)$, while for groundnut the opposite was observed $(P=0 \cdot 033)$. For all the crops combined, the incidence in roots (194 of 2088 plants) was equivalent to that observed in leaves (202 of 2013 plants) $(P=0 \cdot 232)$, indicating systemic virus infection. After greenhouse incubation, the progress of virus incidence in leaves was very similar to that in roots, and both were much higher than the incidence in leaves tested immediately after retrieval from the field $(P \leq 0 \cdot 001)$, in which the virus was undetectable in most of the crops. Only wheat showed a peak of virus incidence in the leaves tested at the time of plant retrieval from the field, on 6 August (Fig. 4e). Virus incidence in wheat plants tested after greenhouse incubation was closely related to weekly rainfall (WR) during the period of exposure in the field (Fig. 4e,g). There were two major periods with high virus incidences, the second week of July and the last part of August, in both cases coinciding with periods of high rainfall. A logarithmic regression could be established between virus incidence in wheat plants and WR recorded during the period of exposure in the field (IPCV-H incidence $=133 \cdot 58+102 \cdot 54 \log [\mathrm{WR}]$; $R=0.79$ with 13 d.f.).

\section{Discussion}

The number of plants analysed during these experiments was generally small (16-32 plants per date of sampling and species), and as a consequence there was considerable variability in the results. Nevertheless, the work was repeated over three rainy seasons in order to follow major 
trends in the epidemiology of clump disease. Distribution and quantity of rainfall, and the hosts, were major factors that influenced epidemiology.

\section{Temperature}

Temperature during the rainy season did not appear to be a limiting factor for disease occurrence in the Hyderabad area. The optimum temperature for infection by $P$. graminis is between 27 and $30^{\circ} \mathrm{C}$. Below $23^{\circ} \mathrm{C}$, infection is suppressed and fungal development is delayed (Legrève et al., 1998). During most of the three rainy seasons, the mean soil temperature varied from 23 to $30^{\circ} \mathrm{C}$ and was thus conducive to infection (Figs 2-4). The virus replicates well over the same range of temperatures as the fungus but, if mechanically inoculated, IPCV can also infect wheat at $15^{\circ} \mathrm{C}$ (Reddy et al., 1988). Temperatures higher than $30^{\circ} \mathrm{C}$ are not favourable to the virus. Symptoms on IPCV-infected groundnut plants collected in the field tended to disappear if the plants were maintained in a greenhouse at temperatures above $30^{\circ} \mathrm{C}$. After a few weeks, the virus itself was difficult to detect by ELISA (D.V.R. Reddy and A.S. Reddy, ICRISAT, India, personal communication).

Seasonal variations in peanut clump disease incidence have been reported (Reddy et al., 1988). Groundnut crops grown in the post-rainy season are negligibly infected and initially, low temperatures prevailing during this season were suspected to be responsible for such low incidence (Reddy et al., 1988). However, high incidence recorded in wheat crops grown during the post-rainy season indicated that temperature was not the only factor involved, and that the host was likely to play an important role (Delfosse et al., 1999).

\section{Rainfall}

The results showed that rainfall appeared to play a significant role in natural infection by $P$. graminis and IPCV. The $P$. graminis life cycle is known to be favoured by alternate watering and drainage (Adams et al., 1986). In contrast, continuous waterlogging is suspected not to be favourable to plasmodiophorids (Ledingham, 1939; Cooper et al., 1976; Inouye, 1977). Soils where peanut clump disease occurs are generally light-textured, ensuring excellent drainage even during the monsoon characterized by heavy rains. In such soils with high drainage, adequate levels of free water for zoospore movement become available with the occurrence of relatively high rainfall. In the field experiments reported here it was apparent that, if heavy rainfall occurred during the period the young seedlings were exposed in the field, it resulted in high P. graminis (1994) and IPCV (1996) incidences. Maraite \& Legrève (1994) reported that $P$. graminis from temperate areas infected barley plants grown in the field, not after the first, but usually after the second rain; thereafter, the number of $P$. graminis-infected plants increased rapidly to reach a plateau 2 months after sowing. The authors suggested that $P$. graminis required a period of rain to provide enough soil moisture and prepare resting spores for germination. In the experiments presented here, a succession of rainy days or a punctual high rainfall was favourable to $P$. graminis infection and to virus transmission. The correlation between virus/vector incidence and rainfall was not easy to demonstrate. In 1994 the virus was not detected in leaves of field-exposed sorghum or millet plants, which showed a transient presence of the virus, while in 1995 high mortality was observed in field-exposed plants and there was no obvious correlation with rainfall.

Drought and heat during storage increase the germinability of $P$. graminis resting spores (Legrève et al., 1999), and groundnut crops sown after the dry, hot summer with the onset of monsoon rains were found to be severely affected by clump disease (Delfosse et al., 1996). The summer (April-June) was drier and hotter in 1996 than in 1994 or 1995 . Consequently, rainfall that occurred in June 1994 and 1995 prior to sowing the groundnut crop may not have been favourable to high disease incidence in those years. Rains allowed establishment of weeds, mostly the monocotyledonous species Cyperus rotundus, an excellent host for P. graminis (Delfosse et al., 1996), which may have trapped some of the inoculum before soil preparation for sowing. In more recent experiments, pearl millet was successfully used as a trap crop to reduce peanut clump disease incidence (Delfosse et al., 1997).

\section{Hosts}

The host ranges of IPCV and $P$. graminis have been studied in the past (Ratna et al., 1991; Delfosse et al., 1996; Legrève et al., 2000), but the various cultivated host crop plants were not compared for their susceptibility to infection and virus movement under natural conditions. In the present study, the various crops analysed during three successive rainy seasons showed clearly different levels of susceptibility to infection by IPCV and $P$. graminis. The hosts showing the highest virus incidences were wheat, barley, maize and groundnut. In groundnut, because infection occurred early, the growth of young plants was suppressed by the virus and the majority of the infected plants showed severe stunting. Groundnut roots are usually devoid of hairs and a distinct epidermis. Root hairs disappear a few days after sowing (Porter et al., 1984; Ramanatha Rao \& Murty, 1994; Sprent, 1994). Groundnut roots have a drying and sloughing surface, and absorption occurs mainly in young primary roots with active meristematic cells underlying the drying outer layer. Therefore a young epidermis should be more susceptible to infection by $P$. graminis than the sloughing and suberized layers that constitute the root surface of old groundnut plants. Recent experiments have demonstrated that the susceptibility of groundnut roots to IPCV infection decreases with age (Delfosse, 2000). It is, however, not advisable to delay sowing groundnut because low temperature or drought at the end of the cropping season can cause a delay in maturity or plant weakness, allowing seed infection by Aspergillus spp., the fungus responsible for aflatoxin contamination (Mehan, 1988). 
The majority of groundnut plants exhibited symptoms 2-3 weeks after virus infection was detected in roots. These observations confirm the reports by Reddy et al. (1988) and Thouvenel et al. (1988) for Indian peanut clump virus and Peanut clump virus, respectively. Groundnut differed from wheat in this respect; while wheat supported fast and systemic virus infection, IPCV movement from roots to leaves was relatively slow in groundnut. Virusinfected groundnut extracts usually gave higher absorbances than wheat extracts in penicillinase-based ELISA tests, probably as a result of lower virus concentration in groundnut than in wheat tissue. The lower susceptibility to infection and slower virus movement in old groundnut plants resulted in lower seed-transmission frequencies for late-infected than early infected plants. Therefore plants that are infected at an early stage represent the major source of virus-infected seed, and seeds from such plants should not be used as a source of sowing material.

Sorghum (ICSV-88036) and pearl millet (ICMH-451) supported $P$. graminis multiplication well, but systemic movement by the virus into leaves seldom occurred in the cultivars studied. In the laboratory and field tests, sorghum could be infected by the virus at the seedling stage. However, a few weeks later the virus could no longer be detected in newly produced leaves. Sorghum and pearl millet are transient and symptomless hosts for IPCV, although it is unclear if the virus causes any yield loss in these crops. Symptomless hosts for IPCV increase the risk of spread and carry-over of clump disease if they are grown in IPCV-infested fields. Indeed, they play an important role in the epidemiology of clump disease because they support $P$. graminis multiplication well and, in addition to groundnut and wheat, the virus is also seed-transmitted in millets and maize (Reddy et al., 1998; Delfosse et al., 1999). Results from the 1994 rainy season showed that $P$. graminis is also present in disease-free areas. There is thus a risk of the vector acquiring virus inoculum arising from seed, leading to the establishment of the disease in new areas. Recent experiments showed that sorghum and pearl millet accessions chosen from the ICRISAT gene bank for their distinct geographical origins differed in their susceptibility to $P$. graminis and IPCV infection (Delfosse, 2000; Legrève et al., 2000). Some sorghum and millet accessions strongly supported systemic virus infection, and therefore may contribute to the production of viruliferous sporosori of $P$. graminis in roots and consequently increase the viruliferous inoculum potential in soils.

Wheat and barley were clearly the hosts showing the highest IPCV incidences during the rainy season under the conditions prevailing in Andhra Pradesh. When grown during the post-rainy season, wheat and barley crops also showed high virus incidences; the virus was seed-transmitted in wheat, and the viral antigen was detected in barley seed (Delfosse et al., 1999). None of the barley roots analysed during the rainy season experiments contained $P$. graminis sporosori. Few $P$. graminis sporosori were detected in roots of the two infected wheat plants. The plasmodiophorid was rarely detected in roots of wheat plants grown in the post-rainy season (Delfosse et al., 1999). However, since 1994 groundnut has been rotated with post-rainy season crops of wheat in the experimental field where a marked increase in virus incidence was observed from 1994 to 1996. Did the wheat crop, despite weak colonization of its roots by $P$. graminis, contribute to a build-up of viruliferous inoculum? Peanut clump is also very severe in fields where groundnut is rotated with wheat in the north Indian state of Rajasthan (Delfosse et al., 1999).

In the experiments reported here, $P$. graminis was not detected in rice roots and IPCV infection seldom occurred in this crop. Rice was shown to host P. graminis in West African countries (Fauquet et al., 1988) and Japan (Usugi, 1988). Rice necrosis mosaic virus, thought to be transmitted by $P$. graminis (Inouye \& Fujii, 1977), was reported to infect rice crops in India (Ghosh, 1981). The present work tested only a single rice cultivar, and further tests are probably required to yield conclusive data on the ability of $P$. graminis from tropical India to develop on rice.

The findings of this study confirm previous results on the host range of $P$. graminis from tropical and subtropical regions of India (Legrève, 1999; Legrève et al., 2000), which showed that only a trace of infection by P. graminis from tropical India occurred on wheat, barley, rice and groundnut, whereas numerous sporosori were observed in sorghum, pearl millet and maize; a few plants of finger millet were also infected. The crops that actively support multiplication of $P$. graminis from tropical India all have $\mathrm{a} \mathrm{C}_{4}$ photosynthetic pathway and are of tropical origin. In contrast, $P$. graminis from temperate areas, including subtropical isolates from Rajasthan in India, has been reported to develop best on $\mathrm{C}_{3}$ plants such as barley, wheat and oats (Barr, 1979; Bastin et al., 1989; Adams \& Jacquier, 1994; Legrève, 1999; Legrève et al., 2000).

\section{Other factors}

Young plants exposed for 1 week in the field, then uprooted and transplanted to a greenhouse environment to allow the fungus to continue its development, showed higher root colonization by $P$. graminis than plants grown in the field and assessed directly. Infection was generally severe, with numerous sporosori of smaller size than in field-grown plants. Results from similar transplanting experiments suggested that younger plants are more susceptible (Usugi, 1988; Adams, 1990). The transplanting of young seedlings appears to be a useful technique for studying the epidemiology of both IPCV and its vector. By allowing virus and $P$. graminis multiplication, this technique permitted the detection of recent infections that were not detected at the time of retrieval from the field. The technique could also prove useful for isolation of $P$. graminis from tropical soils, which is difficult (Legrève, 1999).

Virus incidence varied greatly during the rainy season. Although portions of the youngest leaves were used for ELISA tests, crop growth can influence virus detection by this method. Crop plants such as maize, millet and 
sorghum have faster aerial and subterranean growth rates than barley, finger millet and wheat. If the rate of plant growth exceeds virus replication and movement, it is possible that ELISA will fail to detect the virus in the youngest leaves, despite its presence in older leaves. Tropical cereal crops such as sorghum and pearl millet showed transient presence of the virus and, usually, one month after infection the virus could no longer be detected. This was confirmed by ELISA tests conducted on leaves at the end of the growing season. Only very rarely did sorghum and pearl millet plants test positive for the presence of the virus. Groundnut, once infected, remained infected, showing a regular increase in disease incidence during the rainy season. In wheat and barley, which exhibited very high virus incidences and systemic infection, disease progress quickly reached a plateau close to the maximum incidence, and remained high throughout the rainy season with only minor variations.

\section{Conclusions}

It has been shown that the crops studied were all hosts for IPCV under natural conditions. However, virus incidence varied greatly according to crop. Crop species that were recently introduced to the Indian subcontinent (groundnut and maize) or that were grown for the purpose of the experiment in an area marginal for their production (wheat and barley), showed the highest incidences. Groundnut and maize are American in origin. The time of their introduction to India, probably the 15th century, is still a source of controversy, but there is a general consensus that their cultivation on a significant scale in India was initiated about 150 years ago (Norman et al., 1984; Sinha \& Bhagat, 1988; Singh \& Nigam, 1997). Pecluviruses have not been reported to occur in America. In contrast, sorghum, pearl millet and finger millet are ancient and traditional crops of Indian agriculture. They were introduced from western and eastern Africa (Norman et al., 1984), where pecluviruses have been reported to occur (Thouvenel et al., 1988; Chatenet \& Saeed, 1995). It is suggested that pecluviruses are not typical groundnut viruses, but actually graminaceous viruses that possibly coevolved in tropical and subtropical areas with wild grasses and cereal crops such as millets and sorghum. This hypothesis is reinforced by the fact that the vector of IPCV, $P$. graminis, multiplies well in millet and sorghum and is often detected in grassy weeds (Delfosse et al., 1996; Legrève et al., 2000). IPCV is a seed-transmitted and soilborne virus with a wide host range and a complex epidemiology. The virus inoculum is multiplied in monocotyledonous hosts in which it causes little damage, but when transmitted to susceptible crops such as groundnut it causes an economically important disease.

The results of these epidemiological studies provided information on which new ways of controlling peanut clump disease could be formulated. Early sowing of the groundnut crop, before the onset of monsoon rains and using judicious irrigation, was shown to be a simple and effective cultural method of reducing disease incidence in irrigated areas (Delfosse, 2000). As a result of the baiting technique used in these experiments to monitor IPCV and P. graminis infection, a trap-cropping method using pearl millet was developed and tested successfully at different sites in India (Delfosse et al., 1997). As P. graminis multiplies intensively in monocots, these should be avoided in cropping systems with groundnut. Various post-rainy season crops that could be rotated with groundnut to reduce peanut clump disease incidence have recently been evaluated (Delfosse, 2000).

\section{Acknowledgements}

We are grateful for technical assistance from S. Prabhakar Reddy, R. Kanaka Reddy, Ch. Ravinder Rao, N. Sujatha and P. Swaroopa. The Belgian Administration for Development Cooperation, Brussels, is sincerely acknowledged for its continuous support and for providing the necessary funds. We also thank J.M. Lenné and M.A. Mayo for their encouragement and critical reading of the manuscript, and M.J.C. Asher and the reviewer for their thorough and very constructive editing.

\section{References}

Adams MJ, 1990. Epidemiology of fungally-transmitted viruses. Soil Use and Management 6, 184-9.

Adams MJ, Jacquier C, 1994. Infection of cereals and grasses by isolates of Polymyxa graminis (Plasmodiophorales). Annals of Applied Biology 125, 53-60.

Adams MJ, Swaby AG, Macfarlane I, 1986. The susceptibility of barley cultivars to barley yellow mosaic virus (BaYMV) and its fungal vector, Polymyxa graminis. Annals of Applied Biology 109, 561-72.

Barr DJS, 1979. Morphology and host range of Polymyxa graminis, Polymyxa betae and Ligniera pilorum from Ontario and some other areas. Canadian Journal of Plant Pathology 1 , 85-94.

Bastin V, Boute C, Maraite H, 1989. Inoculum potential and host range of Polymyxa graminis. EPPO/OEPP Bulletin 19, 541-6.

Chatenet M, Saeed I, 1995. First report of sugar cane red leaf mottle virus in Sudan. Plant Disease 79, 321.

Cooper JI, Jones RAC, Harrison BD, 1976. Field and glasshouse experiments on the control of potato mop-top virus. Annals of Applied Biology 83, 215-30.

Delfosse P, 2000. Epidemiology and Management of the Indian peanut clump virus. Louvain-la-Neuve, Belgium: Université catholique de Louvain, $\mathrm{PhD}$ Thesis.

Delfosse P, Bashir M, Malik SN, Reddy AS, 1995. Survey of groundnut virus diseases in Pakistan. International Arachis Newsletter 15, 51-2.

Delfosse P, Devi PS, Legrève A, Wesley SV, Reddy AS, Maraite H, Reddy DVR, 1996. Strategies for management of Indian peanut clump virus. In: Reddy DVR, Gowda CLL, eds. Groundnut Virus Diseases in the Asia-Pacific Region: Summary and Recommendations of the Fourth Meeting of the International Working Group, 12-4 March 1995, Khon Kean University, Thailand. Patancheru, India: ICRISAT, 22-3. 
Delfosse P, Reddy AS, Devi KT, Devi PS, Reddy DVR, 1997. Pearl millet as a bait crop for the management of the Indian peanut clump virus. Indian Journal of Plant Protection 25, $70-2$.

Delfosse P, Reddy AS, Legrève A, Devi PS, Thirumala Devi K, Maraite H, Reddy DVR, 1999. Indian peanut clump virus infection on wheat and barley: symptoms, yield loss and transmission through seed. Plant Pathology 48, 273-82.

Dhery M, Germani G, Giard A, 1975. Résultats de traitements nématicides contre la chlorose et le rabougrissement en Haute-Volta. Cahiers ORSTOM, Sèrie Biologie 3, 161-7.

Dollet M, Dubern J, Waliyar F, Manohar SK, 1993. Distribution of peanut clump virus (PCV), a virus with high symptoms variability. In: Hiruki C, ed. Proceedings of the Second Symposium of the International Working Group on Plant Viruses with Fungal Vectors. Denver, CO, USA: American Society of Sugar Beet Technologists, 149-52.

Fauquet C, Thouvenel J-C, Fargette D, Fishpool LDC, 1988. Rice stripe necrosis virus: a soil borne rod-shaped virus. In: Cooper JJ, Asher MJC, eds. Developments in Applied Biology II. Viruses with Fungal Vectors. Wellesbourne, UK: Association of Applied Biologists, 71-82.

Ghosh SK, 1981. Weed hosts of rice necrosis mosaic virus. Plant Disease 65, 602-3.

Gomez KA, Gomez AA, 1984. Statistical Procedures for Agricultural Research, 2nd edn. Singapore: John Wiley \& Sons.

Inouye T, 1977. Rice necrosis mosaic, a soil borne virus disease. Tropical Agriculture Research Series 10, 185-8.

Inouye T, Fujii S, 1977. Rice necrosis mosaic virus. CMI/AAB Descriptions of Plant Viruses No. 172. Wallingford, UK: CAB International.

Konaté G, Barro N, 1993. Dissemination and detection of peanut clump virus in groundnut seed. Annals of Applied Biology 123, 623-7.

Ledingham GA, 1939. Studies on Polymyxa graminis, n. General n.sp., a plasmodiophoraceaous root parasite of wheat. Canadian Journal of Research, Series C 17, 38-51.

Legrève A, 1999. Vers une Définition plus Large de Polymyxa graminis Ledingham. Louvain-la-Neuve, Belgium: Université catholique de Louvain, PhD Thesis.

Legrève A, Delfosse P, Vanpee B, Goffin A, Maraite H, 1998. Differences in temperature requirements between $P$. graminis of Indian origin and Polymyxa graminis and Polymyxa betae from temperate areas. European Journal of Plant Pathology 104, 195-205.

Legrève A, Vanpee B, Delfosse P, Maraite H, 1999. High temperature during storage favours infection potential of resting spores of Polymyxa graminis of Indian origin. Annals of Applied Biology 134, 163-9.

Legrève A, Vanpee B, Delfosse P, Maraite H, 2000. Host range of tropical and subtropical isolates of Polymyxa graminis. European Journal of Plant Pathology 106, 379-89.

Manohar SK, Dollet M, Dubern J, Gargani D, 1995. Studies on variability of peanut clump virus: symptomatology and serology. Journal of Phytopathology 143, 233-8.

Maraite H, Legrève A, 1994. Polymyxa graminis: vecteur des mosaïques. Mosaïques des Céréales Transmises par Polymyxa graminis Led. Recueil des Communications, 7-8 Avril 1994, Blois, France. Paris, France: Institut Technique des Céréales et des Fourrages, 15-8.
Maraite H, Goffart J-P, Bastin V, 1988. Development of a quantitative method for assessment of Polymyxa graminis Led. Inoculum potential in soils. In: Cavalloro R, Sunderland KD, eds. Integrated Crop Protection in Cereals. Proceedings of a Meeting of the EC Experts' Group. Rotterdam, the Netherlands: Balkema, 259-66.

Mehan VK, 1988. The mycotoxin problem. In: Reddy PS, ed. Groundnut. New Delhi, India: Indian Council of Agricultural Research, 526-41.

Nolt BL, Rajeshwari R, Reddy DVR, Bharathan N, Manohar SK, 1988. Indian peanut clump virus isolates; host range, symptomatology, serological relationships, and some physical properties. Phytopathology 78, 310-3.

Norman MJT, Pearson CJ, Searle PGE, 1984. The Ecology of Tropical Food Crops. London, UK: Cambridge University Press.

Porter DM, Smith DH, Rodriguez-Kabana R, eds, 1984. Compendium of Peanut Diseases. St Paul, MN, USA: American Phytopathological Society Press.

Ramanatha Rao V, Murty UR, 1994. Botany - morphology and anatomy. In: Smartt J, ed. The Groundnut Crop - A Scientific Basis for Improvement. London, UK: Chapman \& Hall, 43-89.

Ratna AS, Rao AS, Nolt BL, Reddy DVR, Vijayalakshmi M, McDonald D, 1991. Studies on the transmission of Indian peanut clump virus disease by Polymyxa graminis. Annals of Applied Biology 118, 71-8.

Reddy AS, Hobbs HA, Delfosse P, Murthy AK, Reddy DVR, 1998. Seed transmission of Indian peanut clump virus (IPCV) in peanut and millets. Plant Disease 82, 343-6.

Reddy DVR, Rajeshwari R, Iizuka W, Lesemannn DE, Nolt BL, Goto T, 1983. The occurrence of Indian peanut clump virus, a soil-borne virus disease of groundnuts (Arachis hypogaea) in India. Annals of Applied Biology 102, 305-10.

Reddy DVR, Nolt BL, Hobbs HA, Reddy AS, Rajeshwari R, Rao AS, Reddy DDR, McDonald D, 1988. Clump disease in India: isolates, host range, transmission and management. In: Cooper JJ, Asher MJC, eds. Developments in Applied Biology II. Viruses with Fungal Vectors. Wellesbourne, UK: Association of Applied Biologists, 239-46.

Reddy DVR, Mayo MA, Delfosse P, 1999. Pecluviruses. In: Granoff A, Webster R, eds. Encyclopedia of Virology, 2nd edn. New York, USA/London, UK: Academic Press, 1196-200.

Singh AK, Nigam SN, 1997. Groundnut. In: Fucillo D, Sears L, Stapleton P, eds. Biodiversity in Trust, Conservation and Use of Plant Genetic Resources in CGIAR Centres. Cambridge, UK: Cambridge University Press, 114-38.

Sinha PK, Bhagat NR, 1988. Origin and history. In: Reddy PS, ed. Groundnut. New Delhi, India: Indian Council of Agricultural Research, 1-11.

Snedecor GW, Cochran WG, 1967. Statistical Methods, 6 th edn. Ames, Iowa, USA: Iowa. State University Press.

Sprent J, 1994. Nitrogen fixation. In: Smartt J, ed. The Groundnut Crop - A Scientific Basis for Improvement. London, UK: Chapman \& Hall, 255-80.

Sudarshana MR, Reddy DVR, 1989. Penicillinase based enzyme-linked immunosorbent assay for the detection of plant viruses. Journal of Virological Methods 26, $45-52$.

Thouvenel J-C, Fauquet C, Fargette D, Fishpool LDC, 1988. Peanut clump virus in West Africa. In: Cooper JJ, Asher MJC, 
eds. Developments in Applied Biology II. Viruses with Fungal Vectors. Wellesbourne, UK: Association of Applied Biologists, 247-54.

Torrance L, Mayo MA, 1997. Proposed re-classification of furoviruses. Archives of Virology 142, 435-9.
Usugi T, 1988. Epidemiology and management in Japan of soil-borne cereal mosaic viruses with filamentous particles. In: Cooper JJ, Asher MJC, eds. Developments in Applied Biology II. Viruses with Fungal Vectors. Wellesbourne, UK: Association of Applied Biologists, 213-26. 
Copyright $\odot 2002$ EBSCO Publishing 